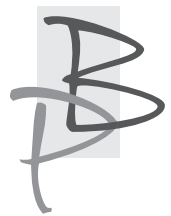

\title{
Maciej Wróblewski*
}

Uniwersytet Mikołaja Kopernika w Toruniu

https://orcid.org/0000-0002-6386-7168

\section{Łotwa „wymyślana” przez Marię Dąbrowską}

Streszczenie: Artykuł jest analizą procesu kreacji („wymyślania”) obrazu Łotwy w dwóch tekstach Marii Dąbrowskiej - Dzienniku małej podróży (1927) oraz U północnych sąsiadów (1929) - będących zapisem tej samej podróży. Zjawisko „wymyślania” obcych kultur i społeczeństw przez pisarzy jest w swej strukturze podobne do tego, według Jamesa Clifforda, jak postępują etnologowie, badający inne kultury i społeczeństwa. Strategię „wymyślania” przez Dąbrowską obrazu jednego z krajów bałtyckich przedstawiono w kontekście notatek o Łotwie i Łotyszach, które pojawiają się na kartach dziennika prowadzonego przez pisarkę od roku 1914. Obok elementów typowych dla mikroanaliz społeczno-kulturowych w Dzienniku małej podróży i w książce U północnych sąsiadów pojawiają się tekstowe świadectwa głęboko emocjonalnego przeżywania krótkiego (trzydniowego) spotkania z kulturą Łotwy, co miało związek, po pierwsze, z osobistą sytuacją pisarki, po drugie

Maciej Wróblewski - dr hab., adiunkt w Instytucie Literatury Polskiej UMK w Toruniu, historyk literatury, badacz dziejów szkolnej i uniwersyteckiej polonistyki. Jest autorem czterech książek: Proza niefikcjonalna w edukacji polonistycznej ucznia szkoły średniej [1855-1939] (Torun 2003), Jan Rymarkiewicz - XIX-wieczny humanista (Torun 2006), Czytanie przyszłości. Polska fantastyka naukowa dla młodego czytelnika (Toruń 2009), Człowiek w przestrzeniach szkoły. Studium antropologiczne (Torun 2014). 
zaś, stanowi interesujący przykład utrwalania czy przepracowywania romantycznego wzorca Północy.

Słowa-klucze: Maria Dąbrowska, Łotwa, podróż, dziennik, reportaż.

\section{„Thinking Up" of Latvia by Maria Dąbrowska}

Summary: This article attempts to show the process of a creation of a picture of Latvia by Maria Dąbrowska. A phenomenon of "thinking up”, according to James Clifford, relates to the ways of description of a foreign culture similar to those used by ethnologists and writers. A core of the process of "thinking up" of a foreign culture includes both an ethnological information, socio-cultural analyses and also the evidences of an author's emotions. The M. Dąbrowska's works Dziennik małej podróży (1927) and U północnych sąsiadów (1929) are a record of a summer travel through the three Baltic countries, Latvia, Lithuania and Finland in 1927. Moreover, M. Dąbrowska also updated what she wrote about this travel in her diary. Short diary notes were expanded on in Dziennik małej podróży and $U$ północnych sąsiadów. Therefore, the process of "thinking up" of Latvia by the author includes particularly tokens of the emotional reactions primarily triggered by her first meeting with the culture and society of Latvia.

Key words: Maria Dąbrowska, travel, diary, reportage.

W okresie międzywojennym Łotwa pojawiała się w polskiej prasie codziennej w kontekście polityki międzynarodowej, w tym szczególnie wojny polsko-bolszewickiej, procesu ustalania przebiegu granic i niepokojów społecznych związanych ze wzmagającymi się pod koniec lat 20. ruchami faszystowskimi. Podobnie jak Polska, tak i Łotwa musiała zmierzyć się z wieloma problemami natury organizacyjnej, społecznej, kulturowej i politycznej, które wynikały ze złożonych relacji między powstałymi w 1918 roku środkowoeuropejskimi państwami a ich największymi sąsiadami - Rosją sowiecką i Niemcami. Polska znajdowała się na zdecydowanie lepszej pozycji niż Łotwa, już to ze względu na liczbę ludności, położenie geopolityczne i rozległość teryto- 
rium, już to ze względu na większy potencjał gospodarczy oraz ugruntowaną, mimo oczywistych różnic między Polakami a mniejszościami narodowymi zamieszkującymi tereny II Rzeczypospolitej, tożsamość narodową ${ }^{1}$.

Społeczeństwo łotewskie $\mathrm{w}$ okresie międzywojennym było bohaterem dłuższych wypowiedzi polskich autorów, wśród których należy wymienić Jana Cynarskiego ${ }^{2}$, attaché prasowego polskiego poselstwa w Rydze, oraz Marię Dąbrowską. Pisarka opublikowała na temat Łotwy tekst o charakterze podróżniczo-reportażowym U pótnocnych sąsiadów (1929). Wcześniej, periodycznie ukazywał się na łamach tygodnika „Kobieta Współczesna” (1927) Dziennik matej podróży, który jest pierwszą, nieco inną w treści i kompozycji, wersją wymienionej książki. Dodać należy, że autorka odnotowała wspomnianą podróż na północ Europy również w systematycznie prowadzonym od roku 1914 diariuszu.

Sądzę zatem, że warto rekonstruować proces „wymyślania” przez Dąbrowską obrazu Łotwy i Łotyszy, uwzględniając trzy wymienione źródła, w których zawarte refleksje w części się pokrywają, ale w części w odmienny sposób oświetlają te same zdarzenia. Nie chodzi jednak o tworzenie rejestru różnic poszczególnych tekstów, ale o wykorzystanie ich do zrekonstruowania literackiego lub, powiedzieć by należało, literacko-reportażowego obrazu jednego z krajów Północy - Łotwy. Wymienione utwory (w części lub w całości) co prawda odnoszą się do tej samej podróży, niemniej jednak powstały w różnym czasie i w odmienny sposób przedstawiają tożsame zdarzenia. To, według mnie, świadectwo procesu kreacji, a więc „wymyślania” Łotwy na wzór „,procederu”, który opisał James Clifford w eseju $O$ etnograficznej autokreacji ${ }^{3}$. Amerykański historyk przekonująco dowodził, analizując Jądro ciemności Josepha Conrada i Dziennik we właściwym sensie tego słowa Bronisława Malinowskiego, że udział pierwiastka kreacyjnego w opisie innych kultur w wypadku pisarza (Conrad) i etnografa funkcjonalisty (Malinowski) jest zbliżony. Podobnie postępuje

1 Zagadnienia historyczne referuję za: A. Albert, Najnowsza historia Polski 1918-1989, wyd. 3, Warszawa 1991 (rozdz. Walka o granice i Wojna polsko-radziecka).

2 Zob. np. J. Cynarski, Łotwa współczesna z 2 mapami i 18 ilustracjami, Warszawa 1925.

J. Clifford, O etnograficznej autokreacji, [w:] tenże, Kłopoty z kultura. Dwudziestowieczna etnografia, literatura i sztuka, przeł. E. Dżurak, J. Iracka, E. Klekot, M. Krupa, S. Sikora, M. Sznajderman, Warszawa 2000. 
autorka Nocy i dni. Dąbrowska „wymyśla” Łotwę, co potwierdzają pierwsze, skrótowe notatki z Dziennika 1914-1945 czytane w kontekście zarówno Dziennika małej podróży, jak i książki U pótnocnych sasiadów. O ile Cynarski ze względu na swoje obowiązki prezentował punkt widzenia specjalisty, osoby bardzo dobrze zorientowanej w historii Łotwy i w jej współczesnych problemach, o tyle autorka Nocy $i$ dni bodaj jako jedyna pisarka okresu międzywojennego przybliżała rodakom łotewską kulturę w formie popularnej, a więc adresowała swoje teksty do szerokiego kręgu czytelników. Warto zatem ten epizod w życiu Dąbrowskiej ująć szerzej, przede wszystkim jako świadectwo konstruowania czy „wymyślania” przez polską intelektualistkę o lewicowych poglądach obrazu kraju, który dla większości Polaków (zapewne nieznających prac Cynarskiego) był mało rozpoznawalny, choć nie „egzotyczny”.

Maria Dąbrowska w lipcu roku 1927 przypadkowo znalazła się na turystycznej trasie, obejmującej trzy bałtyckie kraje: Łotwę, Estonię i Finlandię 4 . Wycieczka została zorganizowana przez Towarzystwo Uniwersytetów Robotniczych. Na marginesie warto odnotować fakt, że pisarka odwiedziła przed I wojną światową Finlandię, czego efektem była publikacja, w której pokazywała Finów jako społeczeństwo potrafiące znakomicie organizować się wokół wartości pracy5 ${ }^{5}$ Północ Europy nie była zatem dla Dąbrowskiej nieznana i obojętna, ale - jak wolno przypuszczać - o nieskrywanej fascynacji tym rejonem Europy decydowały także lektury dziewiętnastowiecznych tekstów. Ogólnie należy stwierdzić, że utrwalony w nich mit romantycznej Północy, charakteryzującej się surowością, tajemniczością i pierwotnością, jest obecny w tekście $U$ pótnocnych sąsiadów we wszystkich trzech częściach, choć najwyraźniej dochodzi do głosu w opisie Finlandii. Ewa Nawrocka sprawę tę ujęła następująco:

Piętno mitycznej Północy w pejzażu ujawniają zwłaszcza opisy Finlandii, szczególnie w warstwie leksyki. To ziemia „najeżona i nasrożona złomami nagich skał”,

4 M. Dąbrowska, U pótnocnych sąsiadów, Warszawa 1929. W pierwszej wersji dziennik podróży drukowany był pod tytułem Dziennik małej podróży na łamach tygodnika „Kobieta Współczesna” (1927, nry 25-36). Obie wersje różnią się szczegółami i układem poszczególnych podrozdziałów; w wypadku części dotyczącej Łotwy w pierwowzorze (Dziennik małej podróży) pojawiło się nieco więcej informacji o charakterze kulturowym, społecznym i polityczno-gospodarczym.

5 M. Dąbrowska, Finlandia, wzorowy kraj kooperacji, Warszawa 1913. 
poszarpana linią szkierów, dominuje w niej „dziko i triumfalnie” skała wdzierająca się nawet do miast i moczar [bagno] .

Być może pisarka, która znajdowała się w trudnym emocjonalnym położeniu, poszukiwała w utrwalonym obrazie Północy duchowego remedium na swój $\operatorname{stan}^{7}$. Donosiła o tym w pierwszym akapicie relacji z podróży w następujących słowach:

Przychodzą na nas czasem jałowe dnie, kiedy śród nastręczających się darów życia stoimy nader bezradni, pogrążeni w rozpatrywaniu swych ran i klęsk i w żałosnym poczuciu, że utraciliśmy instynkt obracania się w tym świecie. Nie wiemy wtedy, co począć, ani czego się imać. W takie godziny niedoli jedynym lekarstwem jest zdecydować się na pierwszą, choćby najbliższą, byle konkretną rzecz, którą nam okoliczności podsuną i za tą rzeczą pójść8.

W dalszej części tekstu tłumaczyła swoją nagłą decyzję wyjazdu od dawna pielęgnowaną w sobie miłością do Północy $(,,[. .$.$] a północ zawsze mnie nie-$ zmiernie nęciła"9). Zatem i trudna sytuacja życiowa, i zainteresowania literacko-kulturowe wespół należy wskazać jako motywację podjęcia trudu podróży. Oczywiście, w działaniu Dąbrowskiej nie ma nic wyjątkowego, bowiem zmiana miejsca, otoczenia kulturowego, a w końcu uczestniczenie w przedsięwzięciu o zbiorowym charakterze, odwracają uwagę osoby odczuwającej „duchowe rozterki" od spraw prywatnych i kierują ku temu, co nowe. Nie znaczy to jednak, że dyskutowane teksty mają charakter wyłącznie terapeutyczny, że w zapiskach z podróży autorki Nocy $i$ dni dochodzą do głosu jedynie jej odczucia i wrażenia. Bynajmniej, ale warstwa emocjonalna w obu wersjach utworu, w pierwotnej, ogłoszonej na łamach tygodnika „Kobieta Współczesna” w dwa

6 E. Nawrocka, Osoba w podróży. Podróże Marii Dąbrowskiej, Gdańsk 2002, s. 94.

7 „Ta wycieczka nie miała dla niej charakteru wyłącznie turystycznego. Motywacja wyprawy na Północ, ujawniona przez Dąbrowską, odsłania egzystencjalny sens tej podróży jako szczególnej terapii w ważnym dla niej i dramatycznym momencie życia. Była w złym stanie ducha, zaledwie dwa lata po śmierci męża, pełna niepokoju i rozgoryczenia niejasnością jej miłosnego związku ze Stanisławem Stempowskim”. E. Nawrocka, dz. cyt., s. 95.

8 M. Dąbrowska, U pótnocnych sąsiadów, s. 7.

9 Tamże, s. 8. 
miesiące po powrocie do Polski, oraz w zredagowanej w postaci książki $U$ pótnocnych sasiadów w dwa lata po zakończeniu podróży, determinuje narrację, która - mimo rzeczowości i oszczędności językowo-stylistycznej - przesycona jest wrażeniami i uczuciami. Pierwszy, dłuższy opis Rygi nie pozostawia wątpliwości co do tego, że autorka Nocy $i$ dni przyjmuje - świadomie bądź nie - postawę w części stylizowaną na romantyczną.

Niezrównana pogoda ozdobiła miasto turkusowym błękitem i powlekła lazurem wszystkie okna. Śród blado płowych i nieozdobnych murów rynku ciemnieje spieczonymi barwami prześliczny kaprys surowego w liniach miasta, bogaty fronton sławnego Domu Czarnogłowców. Tu zatrzymujemy się dłużej, oglądamy wnętrze tej gospody wędrownych, nieżonatych kupców, mających za patrona świętego Maurycego, który, jak mówią, był Murzynem. Olbrzymie portrety rosyjskich cesarzy panują sobie tu nadal w przestronnej sali przyjęćc ${ }^{10}$.

Dąbrowska-turystka mimo emocjonalnego pobudzenia wywołanego - raz - nie tak odległymi przeżyciami osobistymi - dwa - reakcjami typowymi dla podróży w „obce kraje”, potrafi być niekiedy rzeczowa w dostarczaniu czytelnikowi informacji na tematy niepierwszorzędne, ale z jakichś względów ważne.

Po trzech godzinach postoju, zjadłszy wszystkie poziomki, jakie były w bufecie, wyruszamy łotewskim już pociągiem do Rygi. Uzyskaliśmy w tym niezwykle gościnnym kraju olbrzymią, 75\% zniżkę na kolei. Wagony są szerokotorowe, rosyjskie, z deskami podnoszonymi do spania. Mijane domy i stacje czynią na mnie wrażenie, jak gdybym wyjechała nie z granic Polski, lecz z granic czasu. Jakbym znalazła się w epoce z przed lat piętnastu, u nas koło Siedlec czy Łomży. Rzadko nawiedzające mnie uczucie, które z pewnym niesmakiem zmuszona jestem konwencjonalnie nazwać dumą narodową, pochłania mnie przez chwilę ${ }^{11}$.

Nadmienić warto, że przywołany cytat pochodzi z tygodnika „Kobieta Współczesna” i zawiera więcej informacji niż ten, który znalazł się w książce U pólnocnych sąsiadów. Zwrócić należy uwagę na motyw temponautyczny,

10 Tamże

11 Tamże, s. 7. 
który podkreśla pewną bliskość obu społeczno-kulturowych przestrzeni. Łotwa nie jest więc krajem tak zupełnie od Polski odmiennym, jak postrzegali ją romantycy, chociaż podobieństwo - jak wynika z dalszych partii tekstu - ma ścisły związek z wielowiekową obecnością na tych terenach Rosji, a wcześniej Rzeczpospolitej, która objęła w swoje posiadanie Inflanty, czyli Łatgalię. Z pewnym wstydem wspomniana przez Dąbrowską „duma narodowa” oddaje typowe dla każdego podróżującego działania o charakterze porównawczym, które na początku oscylują wokół kategorii „my - oni” i „swój - obcy”. Potem odwiedzany kraj wraz ze swoją kulturą przestaje być konfrontowany z Polską. Im bardziej podróż rozwijała się i pochłaniała licznymi atrakcjami, tym mniej pozostawało czasu i emocjonalnego rezerwuaru na powracanie myślą do ojczyzny. To jedna $\mathrm{z}$ bardziej typowych dla turysty postaw ${ }^{12}$.

W narracji, oddającej szybkie tempo przemieszczania się całej grupy Polaków od jednej do drugiej ,atrakcji” turystycznej, doskonale odbija się przede wszystkim pragnienie pisarki odbudowania sił psychicznych, a nie jakieś szczególne zainteresowanie Łotwą. Zgoła odmiennie jest w wypadku Finlandii, która znalazła się na mapie podróży jako ostatnia, ale zarazem Dąbrowska poświęciła jej najwięcej miejsca. Deklarowała nawet, że chętnie powróciłaby w to szczególne, gdy o naturę i kulturę chodzi, miejsce na mapie Europy, wywołujące w niej coś na kształt „,nostalgicznego entuzjazmu”" ${ }^{3}$. Co prawda autorka Nocy $i$ dni mniej zachwytu wyrażała w związku z trzydniowym pobytem na Łotwie, ale i tu potrafiła dostrzec sprawy dla niej - jako pisarki i działaczki społecznej ważne: wysoki poziom alfabetyzacji społeczeństwa, dobrze rozwinięty ruch czytelniczy oraz pozytywne skutki umiejętnie przeprowadzonej reformy rolnej.

Postawa Dąbrowskiej wobec dopiero co odrodzonej państwowości łotewskiej nie może być uznana za typową dla przeciętnego Polaka okresu międzywojennego, ale na pewno $\mathrm{w}$ jej publikacji pojawiają się elementy charakterystyczne w sposobie oceny przemian obejmujących tę część Europy,

12 Pojęcie turysty używam w znaczeniu, które nadał mu Dean MacCannella w książce Turysta. Nowa teoria klasy próżniaczej (przeł. E. Klekot, A. Wieczorkiewicz, Warszawa 2002). Istotnym elementem koncepcji nowoczesnego turysty jest proces zwiedzania jako rodzaj emocjonalnego i intelektualnego zaangażowania, które pozwala zbudować ciągłą narrację o pewnych miejscach na podstawie niewielkiej ilości informacji (atrakcji) i doświadczeń kulturowych.

13 M. Dąbrowska, U pótnocnych sąsiadów, s. 105. 
wyrażanych przez postawę dumy narodowej, uobecniającej się choćby w sztuce, aż po faszyzujące ruchy polityczne. Pisarka miała świadomość złożoności sytuacji społeczno-politycznej w Europie Środkowowschodniej, ale z pewnością brakowało jej krytycyzmu i - być może - umiejętności szerszego spojrzenia na przemiany społeczne, polityczne i kulturowe w krajach takich, jak Łotwa, które po blisko siedmiuset latach odzyskały niepodległość. Doświadczenie Łotyszy dążących do samookreślenia się jako naród, co odzwierciedlały i sztuka, i postawy w życiu codziennym, nie mogło być wprost odnoszone do współczesnych im zachowań Polaków. Dąbrowska o tych różnicach w tekście $U$ pótnocnych sąsiadów nie napisała, ale pierwsze spotkanie ze społecznością łotewską w Rydze może być odczytywane właśnie jako emocjonalnie wyrazisty zapis krótkiego i intensywnego przeżywania kultury odmiennej od polskiej, ukraińskiej czy - ujmując sprawę szerzej - słowiańskiej. Choć trzeba dodać, że w pierwszej wersji dziennika podróży, publikowanej we fragmentach na łamach „Kobiety Współczesnej”, więcej można znaleźć czynionych przez Dąbrowską uwag i obserwacji oddających pełen dynamizmu proces organizowania się Łotyszy wokół odzyskanej niepodległości.

Niewątpliwie, odwiedzając Łotwę, autorka Nocy $i$ dni dostrzegła w tym kraju podwyższoną temperaturę sporów politycznych i różne pod względem jakości artystycznej próby wyrażenia przez Łotyszy władzy nad swoją tożsamością po długim okresie kolonizacji, w którym i Polacy mieli swój udział. Odnotowała również i to, że społeczno-polityczne życie Bałtów niekiedy zwrócone było przeciwko demokracji. Miała jednak świadomość, że nacjonalizm łotewski był reakcją społeczeństwa żyjącego przez setki lat w podległości.

Politykę okresu międzywojennego dręczył powracający obraz liberalnych demokracji, które kolejno padały ofiarą dyktatury. Mocarstwa zachodnie miały nadzieję, że odniesione przez nie zwycięstwo stanie się początkiem ery ukształtowanej na ich własny obraz i podobieństwo. [...] Niemal każdego roku w tym czy innym państwie ludzie widzieli, jak ich demokratycznej konstytucji zadaje gwałt taki czy inny dyktator ${ }^{14}$.

14 N. Davis, Europa, przeł. E. Tabakowska, Kraków 1999, s. 1001. 
Reportażowo-podróżniczy zapis Dąbrowskiej, czytany choćby w kontekście publikacji Cynarskiego, stanowi interesujące świadectwo procesu budowania („wymyślania”) przez pisarkę obrazu dotąd mało znanej kultury łotewskiej. Jak dowiadujemy się z jej dziennika, pomysł opisania kilkudniowej podróży na Łotwę, Estonię i do Finlandii w postaci książki wyszedł ze strony początkującego wydawcy:

A, prawda, przed świętami wyszła moja książeczka U północnych sąsiadów. Opis mojej podróży na Łotwę, do Estonii i do Finlandii. Wydał ją początkujący księgarz-wydawca Jerzy Markiewicz, bardzo ładny chłopiec, ale zdaje się, że i z całego jego przedsięwzięcia, i z mojego honorarium będą nici ${ }^{15}$.

Ten literacki drobiazg, napisany przy okazji głównej pracy nad powieścią Noce $i$ dnie, odsłania najbardziej rzucające się w oczy polskiej turystki znamiona „ducha Łotwy i Łotyszy”. A zatem wrażenia, odczucia i emocje stanowią w jej zapiskach z podróży zasadniczy element narracji osoby, która wespół z innymi, odwiedzała „północnych sąsiadów” Polski. Chronologicznie pierwsze zapisy dziennikowe oddają pośpieszny rytm wycieczkowy, niesprzyjający głębszym refleksjom, a zatem wydają się najbardziej autentyczne - tak w odniesieniu do emocji, jak i uwag czy mikroanaliz społeczno-kulturowych na temat Łotyszy i Łotwy - niż periodyczna publikacja na łamach „Kobiety Współczesnej” oraz wersja książkowa U pótnocnych sąsiadów. Łotwie pisarka poświęciła trzy krótkie dziennikowe notatki, w których znaleźć można kilka informacji rozbudowanych w późniejszych publikacjach: wysoki artystyczny poziom sztuki chóralnej, okalające Rygę mury oraz wrażenia z projekcji propagandowego filmu.

O strategii kreowania przez pisarkę obrazu nastrojów społecznych wśród Łotyszy wymownie świadczy tytuł jednego z rozdziałów książki $U$ pótnocnych sasiadów - Ryga petna powagi. Otwierający go passus wydaje się być typowy dla kogoś, kto przybywa do kraju ocenianego jako „słabszy”, „mniejszy”, a przez to permanentnie zagrożony z powodu geopolitycznego położenia:

15 M. Dąbrowska, Dzienniki 1914-1945, T. 2, wyb. wstęp i przypisy T. Drewnowski, Warszawa 1999, s. 153. 
Ryga jest skupiona, niezwykle jak na miasto portowe spokojna, nie miniemy się z prawdą, kiedy powiemy, że poważna i cicha. Wygląda nader wyraźnie na stolicę niedużego narodu, który nie może pozwolić sobie na żadną lekkomyślność, na żaden nieprzewidziany wyskok nadmiaru życia, zanim nie powie światu za pomocą swych nowych dziejów, że jest narodem, pomimo wszystko, wielkim ${ }^{16}$.

Ten rodzaj historiozoficznego opisu Łotwy przez pryzmat tętna życia Rygi nie pojawia się w dzienniku, można zatem uznać go za sporządzony z pewnego dystansu czasowego i w warunkach determinowanych społeczno-politycznym życiem sanacyjnej Polski. Dąbrowska nie tyle próbuje zrozumieć specyfikę kraju, którego mieszkańcy przepracowują setki lat kolonizacji, ile - co wydaje się być typowe dla tego typu tekstów - rejestruje swoje wrażenia, nadając im formę dyskursywną. Dąbrowska tworzy tekst na temat Łotwy z perspektywy turystki, która przybyła z kraju - w mniemaniu autorki Nocy $i$ dni - o ugruntowanej kulturze, co niekiedy jest powodem okazywania wyższości wobec Łotyszy. Co ciekawe, w książce U pótnocnych sąsiadów obok kilku zaledwie uwag o historiozoficznym i politycznym charakterze zdecydowanie więcej jest świadectw pewnego rodzaju stanu turystycznej euforii i zachwytu, wywołanych doznaniami artystycznymi (występy chóru) i estetycznymi (piękno Dźwiny). To z kolei przekłada się także na sposób objaśniania sobie i czytelnikom sytuacji społeczno-politycznej Łotwy. Zawiłe dzieje narodu pisarka konstatuje w następujący sposób:

Łotwa, ten Wielki Nieznajomy pośród narodów, była i dla mnie, wyznam to, pewnego rodzaju zagadką. Jadąc do Rygi nie bez trudu usiłowałam się połapać, gdzie i od czego zaczyna się ten naród ${ }^{17}$.

Kolejne rozważania, których w dzienniku brak, odnoszą się do spraw, będących dla polskiej pisarki swego rodzaju odpowiedzią na pytanie o to, kim są Łotysze.

Zaczyna się od pieśni [...], a na morzu się kończy. Oto granice, w których bez względu na obszar kraju, liczbę ludności i państwową [...] dziewiczość, nie może

17 Tamże, s. 18. 
się zawierać nic marnego, ani mało ważnego - oto niebylejakie granice bytu, oto granice wzniosłe $^{18}$.

Ten upraszczający i nieklarowny opis „ducha Łotwy” w dalszych partiach tekstu nabrał ostrości. Dąbrowska bowiem doceniła poziom alfabetyzacji wśród Łotyszy, wysoki poziom szkolnictwa oraz umiejętne przeprowadzenie reformy rolnej. Nadto dostrzegła, że Łotysze w krótkim czasie potrafili wykorzystać swoje położenie geopolityczne do tego, by stać się ważnym w Europie krajem tranzytowym.

Mimo oczywistych różnic treściowych i strukturalnych między pisanym na bieżąco diariuszem a Dziennikiem małej podróży i książką $U$ pótnocnych sąsiadów wspólna jest - wyrażana wprost i nie wprost - ciekawość Dąbrowskiej kultury łotewskiej i Łotyszy. Krótkie, kurtuazyjne spotkanie uczestniczek wycieczki z pisarzem Rainisem (właśc. Jānisem Pliekšānsem) pełne nieporozumień skrupulatnie odnotowanych w zapisie diarystycznym, okazuje się być pretekstem do krótkiej charakterystyki twórczości zarówno jego, jak i małżonki Aspazji (właśc. Elza Pliekšāne, wcześniej Johanna Emīlija Lizete Rozenberga). Trudno jednoznacznie stwierdzić, czy Dąbrowska zapoznała się z którymkolwiek utworem małżeństwa, bowiem zarówno w tekście $U$ pótnocnych sąsiadów, jak i w dzienniku pojawiają się jedynie krótkie scenki rodzajowe oraz powierzchowne charakterystyki obojga pisarzy, natomiast brak jest odniesień do ich konkretnych utworów.

Dąbrowska thumaczyła swoją niewiedzę w tym zakresie barierami językowymi, a także niewielką - lub żadną - obecnością współczesnej literatury łotewskiej w świadomości literackiej Polaków. Natomiast w tekstach Cynarskiego, opublikowanych dwa lata przed podróżą autorki Nocy $i$ dni na Łotwę, scharakteryzowana została twórczość obojga pisarzy. Ponadto przedstawił on twórczość innych artystów: Rūdolfsa Blaumanisa, dramaturga i autora prozy realistycznopsychologicznej, tragicznie zmarłego dramatopisarza i nowelisty Jānisa Poruksa oraz poety i powieściopisarza Andrievsa Niedry. O ile łotewska literatura piękna była dla Dąbrowskiej raczej terra incognita - i zapewne taka pozostała później - o tyle literatura tradycyjna, a w szczególności pieśni wykonywane przez chór w operze ryskiej, wywarły bardzo duże wrażenie na pisarce. Wspomniała o tym 
artystycznym doświadczeniu zarówno w diariuszu, jak i w Dzienniku małej podróży oraz w tekście U pólnocnych sąsiadów. Mimo to pisarka w publikacji nie zamieściła choćby krótkiej wzmianki o folklorze łotewskim, który jest formalnie zróżnicowany i tematycznie interesujący. Zdecydowanie więcej informacji na ten temat przynosi rzeczowa publikacja Cynarskiego, który, opisując dorobek artystyczny Łotyszy, wprost napisał, że zbiór pieśni ludowych Dainas zebranych przez Krišjānisa Baronsa „,[...] stanowi klucz duszy zbiorowej ludu łotewskiego przed niewolą i w pierwszych wiekach niewoli niemieckiej"19. Dalej Cynarski podkreślił fakt, że tradycyjna literatura łotewska liczy sobie około 35 tysięcy pieśni, które wraz z licznymi wariantami dają w sumie 220 tysięcy tekstów ${ }^{20}$. Są wśród nich zarówno pieśni religijne, związane z narzuconym Łotyszom chrześcijaństwem, świeckie, jak i pochodzące z czasów pogańskich, określone jako pieśni święte. Autor rozprawy o międzywojennej Łotwie określa owe pieśni „zbiorową poezją ustną”, która nie tylko jest emanacją „,ducha Łotwy”, ale także stanowi świadectwo przemian językowych. Z tej tradycji wyrósł między innymi poemat dramatyczny Rainisa Ogień i noc, który powstawał w latach 1903 - 1904.

Jak zatem Maria Dąbrowska spoglądała na Łotwę i Łotyszy we wskazanych krótkich wzmiankach diarystycznych, w Dzienniku małej podróży i w trzech rozdziałach tekstu $U$ pótnocnych sqasiadów? Nade wszystko dominuje u niej postawa turystki, która przyjechała do „dalekiego” i „małego” kraju z zamiarem zobaczenia i „mocnego” przeżycia jak największej ilości wrażeń, a nie w celu zrozumienia kultury odmiennej od własnej. Ten motyw w wypadku opisu podróży po Łotwie wydaje się być obecny najmniej w porównaniu z Finlandią. Znamienny i niepozbawiony autentyzmu jest fragment, w którym autorka Nocy $i$ dni analizuje relacje między Łotyszami a Polakami na podstawie wysłuchanych oficjalnych mów:

Bo jeżeli my mieliśmy byli uprzedzenia do Łotyszów, ale wyzbywamy się ich teraz, to Łotysze swoje uprzedzenia dziś właśnie potęgują. W mowach, jakie wygłosili do naszej wycieczki minister oświaty, poeta pan Rainis, i minister spraw zagranicznych, p. Cielens, zauważyliśmy coś podobnego do ostrożnej nieufności,

19 J. Cynarski, Łotwa współczesna z 2 mapami i 18 ilustracjami, Warszawa 1925, s. 121.

20 O tym fakcie wspomniała M. Dąbrowska w Dzienniku małej podróży, ale w wersji książkowej te informacje już się nie znalazły. 
a nawet do jakiegoś nieco śmiesznego lęku wobec Polski. Były to jednak raczej, jak sądzę, odbicia panującego właśnie prądu oficjalnej polityki niż istotnego nastroju społeczeństwa21.

Jak widać z przytoczonych słów, mimo zaledwie trzech dni, które pisarka spędziła w Rydze, potrafiła niekiedy subtelnie oddzielić dyskurs publiczny, oparty na pewnych politycznych i międzynarodowych kalkulacjach, od bezpośrednich, autentycznych relacji między Łotyszami a Polakami.

W opisie podróży na Łotwę dominują silne emocje, wywoływane przez sztukę chóralną, naturę i zabytki architektoniczne. Ta pozorna banalizacja doświadczenia obecnego w zapisie procesu „wymyślania” innej, dotąd nieznanej dla Dąbrowskiej kultury, odznacza się dużą dozą autentyzmu i szczerością emocjonalną. Ze względu na zbyt duże tempo wycieczki oraz barierę językową sposób poznawania nowej kultury i obcego społeczeństwa musiał zatrzymać się na pewnym stopniu ogólności. Pisarka nie wchodziła w interakcje $\mathrm{z}$ autochtonami, mogła zaledwie ich obserwować. Na tym poziomie zatem tekst $U$ pótnocnych sasiadów konfrontowany z tekstem Dziennika matej podróży i uzupełniony o wskazane zapiski diarystyczne ma walor dokumentu emocjonalnego.

\section{Bibliografia}

Albert A., Najnowsza historia Polski 1918-1989, wyd. 3, Warszawa 1991.

Clifford J., O etnograficznej autokreacji, [w:] tenże, Kłopoty z kulturą. Dwudziestowieczna etnografia, literatura i sztuka, przeł. E. Dżurak, J. Iracka, E. Klekot, M. Krupa, S. Sikora, M. Sznajderman, Warszawa 2000.

Cynarski J., Łotwa współczesna z 2 mapami i 18 ilustracjami, Warszawa 1925.

Davis N., Europa, przeł. E. Tabakowska, Kraków 1999.

Dąbrowska M., Dziennik małej podróży, „Kobieta Współczesna” 1927, nr 25-36. 
Dąbrowska M., Dzienniki 1914-1945, t. 2, wyb. wstęp i przypisy T. Drewnowski, Warszawa 1999.

Dąbrowska M., Finlandia, wzorowy kraj kooperacji, Warszawa 1913.

Dąbrowska M., U północnych sąsiadów, Warszawa 1929.

MacCannell D., Turysta. Nowa teoria klasy próżniaczej, przeł. E. Klekot, A. Wieczorkiewicz, Warszawa 2002.

Nawrocka E., Osoba w podróży. Podróże Marii Dąbrowskiej, Gdańsk 2002. 